\title{
EVALUATION OF PARTICULATE MATTER (PM10) DISTRIBUTIONS IN IZMIR USING GEOGRAPHIC INFORMATION SYSTEMS FOR SMART CITIES APPLICATIONS
}

\author{
Kadir Ulutaş ${ }^{1}$, Sohaib K. M. Abujayyab² ${ }^{\text {, İbrahim Ratıp KARAŞ }}{ }^{1}$ \\ ${ }^{1}$ Karabuk University, Faculty of Engineering, Department of Environmental Engineering, 78050, Karabuk, Turkey \\ ${ }^{2}$ Karabuk University, Department of Geography, 78050, Karabuk, Turkey.
}

KEY WORDS: Particulate Matter (PM10), Izmir, Geographic Information Systems, Smart Cities Applications, Interpolation.

\begin{abstract}
:
In this study, PM10 values from the air quality monitoring station in Izmir was evaluated. 9 stations could be used in this study, since PM10 data are suitable to evaluate for the years 2020-2019-2018. The 4-season and annual PM10 distribution map for 3 years was prepared using ArcGIS. The benefits of these maps to city managers in the smart city application were expressed. In addition, PM10 data of 9 stations were evaluated according to legal limit values. It was determined that Aliağa and Gaziemir stations exceeded the limit values more than other stations. It has been observed that different sources of air pollution such as industry, traffic and heating affect different districts. When the number of days exceeding the limit value and the number of days without measurement are evaluated together, it is seen that the limit values are exceeded by all stations.
\end{abstract}

\section{INTRODUCTION}

It is possible to define urbanization as industrialization and population growth in a region due to the migration of people from rural areas to urban areas (Uttara et al. 2012). Industrialization, which is an indicator of the positive acceleration in the level of urbanization and development, is the most basic component of a prosperous life in regional and national terms. As industrialization causes population growth, it increases the demand for housing. This situation triggers modern urbanization and the development of quality living spaces. The increase in the number of vehicles due to the increasing economic purchasing power, the new roads built, the transportation sector serving the industry and the public transportation vehicles reveal the importance of traffic in urban life. Although all these developments differ from region to region, sometimes it can be more in some provinces. Therefore, it can cause various environmental problems, especially air pollution, in these provinces.

Industry, residences and traffic can be shown as the main sources of air pollution. Particulate matter (PM) is one of the most important parameters among air pollutants. The term PM refers to solid and liquid substances that are suspended in air (Demirarslan and Kaya 2017). It is stated in the literature that the sources of PM are $25 \%$ traffic, $22 \%$ combustion, $20 \%$ home heating, $18 \%$ natural and $15 \%$ industry (Demirarslan and Akıncı 2016; Demirarslan 2016). The particle size of PM is one of the most important properties that determine its suspension time in the atmosphere, its transport in the atmosphere, its precipitation and its health effect (Ayberk 2002; Ergenekon and Ulutaş 2014; Taşdemir 1999; Taşdemir and Çağlar 2002).

An adult person breathes approximately $20 \mathrm{~m} 3$ of air per day (USEPA 2002). For this reason, determining the content of the ambient air we breathe is a very important issue in terms of health and quality of life. Exposure to PM, especially PM10 $(\leq 10 \mu \mathrm{m})$, PM2.5 $(\leq 2.5 \mu \mathrm{m})$, PM1 $(\leq 1 \mu \mathrm{m})$, is known to have adverse effects on human health (Heal et al. 2012). Many epidemiological studies have shown that exposure to PM increases mortality (Janssen et al. 2013; Kan et al. 2007; Namdeo and Bell, 2005). Various respiratory diseases such as lung cancer (Turner et al. 2011; Vineis et al. 2006), asthma (Dorevitch et al. 2006; Eggleston et al. 1999) and kidney problems (Spencer-Hwang et al. 2011; Weng et al. 2015) have been shown to be associated with excessive breathing of air with high concentrations of PM10 and PM2.5. In addition, the study by Ergenekon and Ulutaş (2014) emphasized that besides PM concentrations, the chemical composition of PM may pose a potential health risk, especially for the local area. Therefore, controlling emissions to protect public health and well-being is one of the primary goals of the air quality management plan. Air quality management takes various measures and plans some actions to achieve this goal within the geographical boundaries of the city (Sivertsen and Bartonova 2012; Laxen 1993).

The air quality in cities in Turkey is evaluated according to the data of the Air Quality monitoring station, which was established in accordance with the Regulation on Air Quality Assessment and Management and operated by the Ministry of Environment and Urbanization (MEU). MEU is the agency responsible for monitoring the pollution levels of pollutants. In addition, it develops principles and standards for the presence of pollutants in the air in an amount and time that will not adversely affect human health and disrupt the ecological balance.

Air pollution level is monitored hourly by 355 air quality monitoring stations throughout Turkey. 22 of these stations are located in Izmir. However, data from 9 stations could be used in this study, since PM10 data are suitable to evaluate for the years 2020-2019-2018. The data for 2020-2019-2018 were evaluated seasonally and annually with the geographic information system (ArcGIS program) (Abujayyab et al. 2017). In addition, these data were examined to legal limit values.

\section{MATERIALS AND METHOD}

\subsection{Study area}

İzmir is the third largest city in Turkey in terms of population $(4,394,694$ people) and its surface area is $11,973 \mathrm{~km} 2$ (TUIK 2021; IG 2021). İzmir is surrounded by Madra Mountains in the north, Kuşadası Bay in the south, Çeşme Peninsula in the west, and Aydın and Manisa provinces in the east. In İzmir, summers are hot and dry; winters are mild and rainy. The fact that the mountains are perpendicular to the sea and the plains extend to the threshold of Inner Western Anatolia allows the marine 
influences to spread to the inner parts. July-August is the hottest snowfall (IPDEU 2021). Study area is shown in Figure 1. and January-February is the coldest. There is little to no

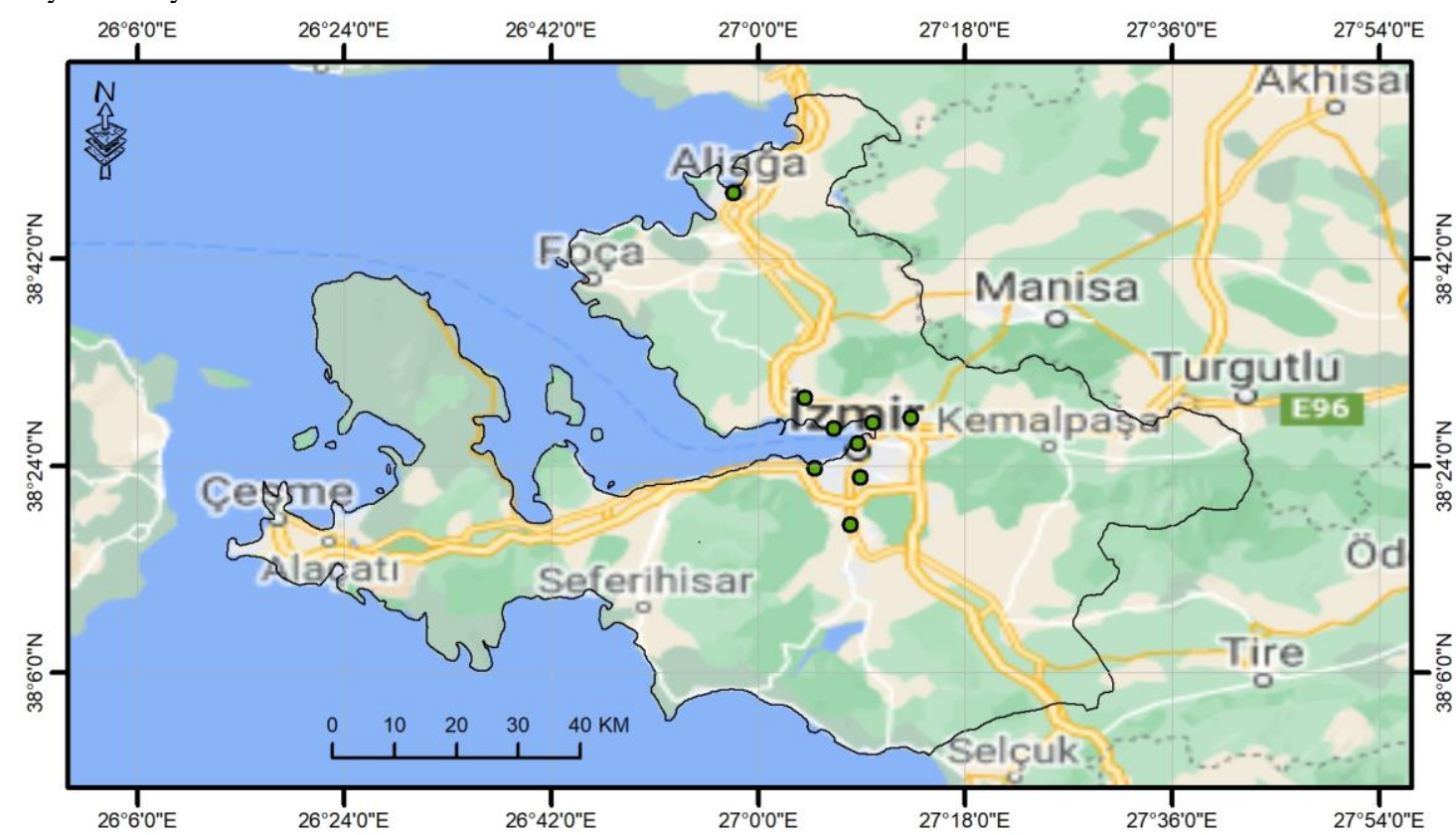

Figure 1. Study area and air quality monitoring stations

\subsection{Data Collection and Method}

İzmir was chosen as the study area because it is the third largest city in Turkey and there are large industrial facilities in different districts. In addition, this province was chosen as the study area, as there are many air quality monitoring stations (more than some other provinces) that allow us to use the ArcGIS program
(Abujayyab and Karas 2019). Data obtained from 9 MEU air quality monitoring stations (Table 1) in Izmir were used in the evaluation (MEU, 2021). Air quality monitoring stations are shown in Figure 1. The air quality monitoring stations from which the data used in the study were taken, the coordinates of these stations and the status of access to the data are given in Table 2.

\begin{tabular}{|c|c|c|c|c|c|c|c|c|c|}
\hline & Aliağa & Alsancak & Bayrakli & Bornova & Çiğli & Gaziemir & Güzelyali & Karşiyaka & Şirinyer \\
\hline Latitude & 26.9646 & 27.1444 & 27.1666 & 27.2213 & 27.0677 & 27.134 & 27.0827 & 27.1097 & 27.1483 \\
\hline Longitude & 38.7948 & 38.4322 & 38.4622 & 38.4691 & 38.498 & 38.3143 & 38.3958 & 38.4541 & 38.3825 \\
\hline $\begin{array}{c}2018 \\
\text { Spring }\end{array}$ & + & 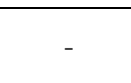 & + & + & + & + & + & + & + \\
\hline $\begin{array}{c}2019 \\
\text { Spring }\end{array}$ & - & + & + & + & + & + & + & + & + \\
\hline $\begin{array}{c}2020 \\
\text { Spring }\end{array}$ & + & + & + & + & + & + & + & + & + \\
\hline $\begin{array}{c}2018 \\
\text { Summer }\end{array}$ & - & - & + & + & + & + & + & + & + \\
\hline $\begin{array}{c}2019 \\
\text { Summer }\end{array}$ & + & + & + & + & + & + & + & + & + \\
\hline $\begin{array}{c}2020 \\
\text { Summer }\end{array}$ & + & + & + & + & + & + & + & + & + \\
\hline $\begin{array}{c}2018 \\
\text { Autumn }\end{array}$ & - & - & + & + & + & + & + & + & + \\
\hline $\begin{array}{c}2019 \\
\text { Autumn }\end{array}$ & + & + & + & + & + & + & + & + & + \\
\hline $\begin{array}{c}2020 \\
\text { Autumn }\end{array}$ & + & + & + & + & + & + & + & + & + \\
\hline $\begin{array}{c}2018 \\
\text { Winter }\end{array}$ & + & - & + & + & + & + & + & + & + \\
\hline $\begin{array}{c}2019 \\
\text { Winter }\end{array}$ & + & + & + & + & + & + & + & + & + \\
\hline $\begin{array}{c}2020 \\
\text { Winter }\end{array}$ & + & + & + & + & + & + & + & + & + \\
\hline
\end{tabular}

Table 1. Air monitoring stations and coordinates 
(+) Measurement records available; (-) No measurement records

In this study, Izmir air quality was evaluated seasonally and annually for the years 2020-2019-2018 in terms of PM10, and a distribution map was created using the ArcGIS program. A point layer was created using the coordinates of the measuring stations in ArcGIS software. Seasonal and annual average concentration values are added to this point layer as feature data. Seasonal and annual PM10 distribution maps were produced for the province of Izmir by using the "Inverse Distance Weighted Interpolation Method (IDW)" in ArcGIS GIS software. In smart city applications, it is aimed to monitor the pollution density spatially by using these maps as layers. Finally, annual PM10 concentrations were compared with Turkey, EU and WHO legal limit values (RAQAM 2008; EU 2008; WHO 2005).

\section{RESULTS AND DISCUSSIONS}

PM10 data from the Air Quality Monitoring Stations in the study area for the years 2018-2020 were entered into the GIS database and seasonal and annual PM10 distribution maps were produced using the Inverse Distance Weighted method in the ArcGIS program.

The map (Figure 2 (a.a-c)) created for the spring season is prepared according to the PM10 averages in March, April and May. When the spring map of 2020 is examined, it is seen that the highest value $(54.44 \mu \mathrm{g} / \mathrm{m} 3)$ was determined in Aliağa and the lowest value $(19.94 \mu \mathrm{g} / \mathrm{m} 3)$ was determined in Karşıyaka stations. The map shows that for the spring of 2019, the highest value $(36.98 \mu \mathrm{g} / \mathrm{m} 3)$ was for Bayrakl1 and the lowest value $(18.35 \mu \mathrm{g} / \mathrm{m} 3)$ was for Karşıyaka stations. In 2018 spring season, it can be seen with the help of the map that Aliağa station had the highest value $(71.74 \mu \mathrm{g} / \mathrm{m} 3)$ and Karşıyaka station the lowest value $(30.45 \mu \mathrm{g} / \mathrm{m} 3)$.

June, July and August data were used in the map (Figure 2(b.ac)) created for the summer season. Aliağa station data had the highest value for 2019 and 2020 (62.39 and $48.94 \mu \mathrm{g} / \mathrm{m} 3)$, while Karş1ka station data had the lowest value for 2018 and $2019(\mu \mathrm{g} / \mathrm{m} 3)$. In 2018, the highest value was determined at the Bornova station $(43.11 \mu \mathrm{g} / \mathrm{m} 3)$, while in 2020 the lowest value was determined at the Güzelyalı station $(22.03 \mu \mathrm{g} / \mathrm{m} 3)$.

The mean PM10 values of September, October, and November were entered into the ArcGIS program to generate the autumn distribution map Figure 2(c.a-c)). The highest values for 2018, 2019 and 2020 were seen at Bayrakl1 (49.77 $\mu \mathrm{g} / \mathrm{m} 3)$, Bornova $(57.97 \mu \mathrm{g} / \mathrm{m} 3)$ and Aliağa $(55.20 \mu \mathrm{g} / \mathrm{m} 3)$ stations, respectively. The lowest values were seen at the Karşıka station for 2018 $(22.44 \mu \mathrm{g} / \mathrm{m} 3)$ and $2019(33.89 \mu \mathrm{g} / \mathrm{m} 3)$, and at the Güzelyalı station for $2020(24.30 \mu \mathrm{g} / \mathrm{m} 3)$.

December, January and February data were used to generate the PM10 distribution map Figure 2(d.a-c) for the winter season. While the highest value was determined at Bayraklı station in $2018(66.53 \mu \mathrm{g} / \mathrm{m} 3)$ and $2019(52.21 \mu \mathrm{g} / \mathrm{m} 3)$, it was determined at Aliağa station in $2020(49.72 \mu \mathrm{g} / \mathrm{m} 3)$. The lowest values were observed at Karşıyaka (42.01 $\mu \mathrm{g} / \mathrm{m} 3)$, Aliağa $(28.09 \mu \mathrm{g} / \mathrm{m} 3)$ and Şirinyer $(25.39 \mu \mathrm{g} / \mathrm{m} 3)$ stations for 2018 , 2019 and 2020, respectively.

Finally, the PM10 distribution map prepared according to the annual averages of 2018, 2019 and 2020 values were shown in Figure 2 (e.a-c). The highest values for $2018(51.84 \mu \mathrm{g} / \mathrm{m} 3)$ and $2019(44.62 \mu \mathrm{g} / \mathrm{m} 3)$ were determined at Bayraklı station, while for $2020(52.14 \mu \mathrm{g} / \mathrm{m} 3)$ it were determined at Aliağa station. The lowest annual average values for 2018 (28.72 $\mu \mathrm{g} / \mathrm{m} 3), 2019$ $(26.49 \mu \mathrm{g} / \mathrm{m} 3)$ and $2020(32.34 \mu \mathrm{g} / \mathrm{m} 3)$ were determined at Karşıyaka station.

\begin{tabular}{|l|c|c|c|}
\hline & $2020\left(\mu \mathrm{g} / \mathrm{m}^{3}\right)$ & $2019\left(\mu \mathrm{g} / \mathrm{m}^{3}\right)$ & $2018\left(\mu \mathrm{g} / \mathrm{m}^{3}\right)$ \\
\hline Spring & 34.75 & 30.18 & 46.68 \\
Summer & 33.32 & 34.13 & 32.26 \\
Autumn & 43.02 & 40.27 & 38.43 \\
Winter & 41.13 & 38.96 & 50.02 \\
\hline
\end{tabular}

Table 2. PM10 seasonal average values

A total of 9 station data were used in this study. However, some stations' data were found to be missing. For the spring season, 1 station data could not be reached in 2019 and 2018. According to these data, the highest average values were determined in 2018, and the lowest average values were determined in 2019. Data for 2 stations could not be reached in 2018 for the summer and autumn seasons. It has been observed that the average values of the summer season are very close to each other. While 2019 was the highest value, the lowest value was determined in 2018. The highest value in the autumn season was determined in 2020 and the lowest value in 2018. For the winter season, 1 station data could not be reached in 2018. According to these data, the highest was determined in 2018 and the lowest in 2019 (Table 2)

The RAQAM and EU annual limit values for 2020 and 2019 are $40 \mu \mathrm{g} / \mathrm{m} 3$. The WHO annual limit value is $20 \mu \mathrm{g} / \mathrm{m} 3$. The RAQAM and EU daily limit value is $50 \mu \mathrm{g} / \mathrm{m} 3$, and the maximum number of days allowed to be exceeded is 35 .

The minimum, maximum and average values of PM10 values for 2020 are given in Table 3. Only Aliağa and Gaziemir stations exceeded the RAQAM and EU annual limit values for 2020. Also, all stations exceeded the WHO limit value. Among all stations, only Şirinyer station is below the unmeasured day limit. The days without measurements were determined as the maximum Aliağa station (30 days) and the least Güzelyalı station (9 days). More measurements were made than in previous years in Aliağa station.

In Table 4, the minimum, maximum and average values of PM10 values for 2019 are given. In 2019, RAQAM and EU annual limit values were exceeded at Bayraklı, Bornova and Güzelyalı stations. The average values of all stations were above the WHO limit value. Except for Aliağa, Karşıyaka and Şirinyer stations, all stations exceeded the unmeasured day limit. There is no data for 331 days at Aliağa station. Although the daily limit value is not exceeded, the inability to measure for days indicates that precautions should be taken for the operation of this station. 

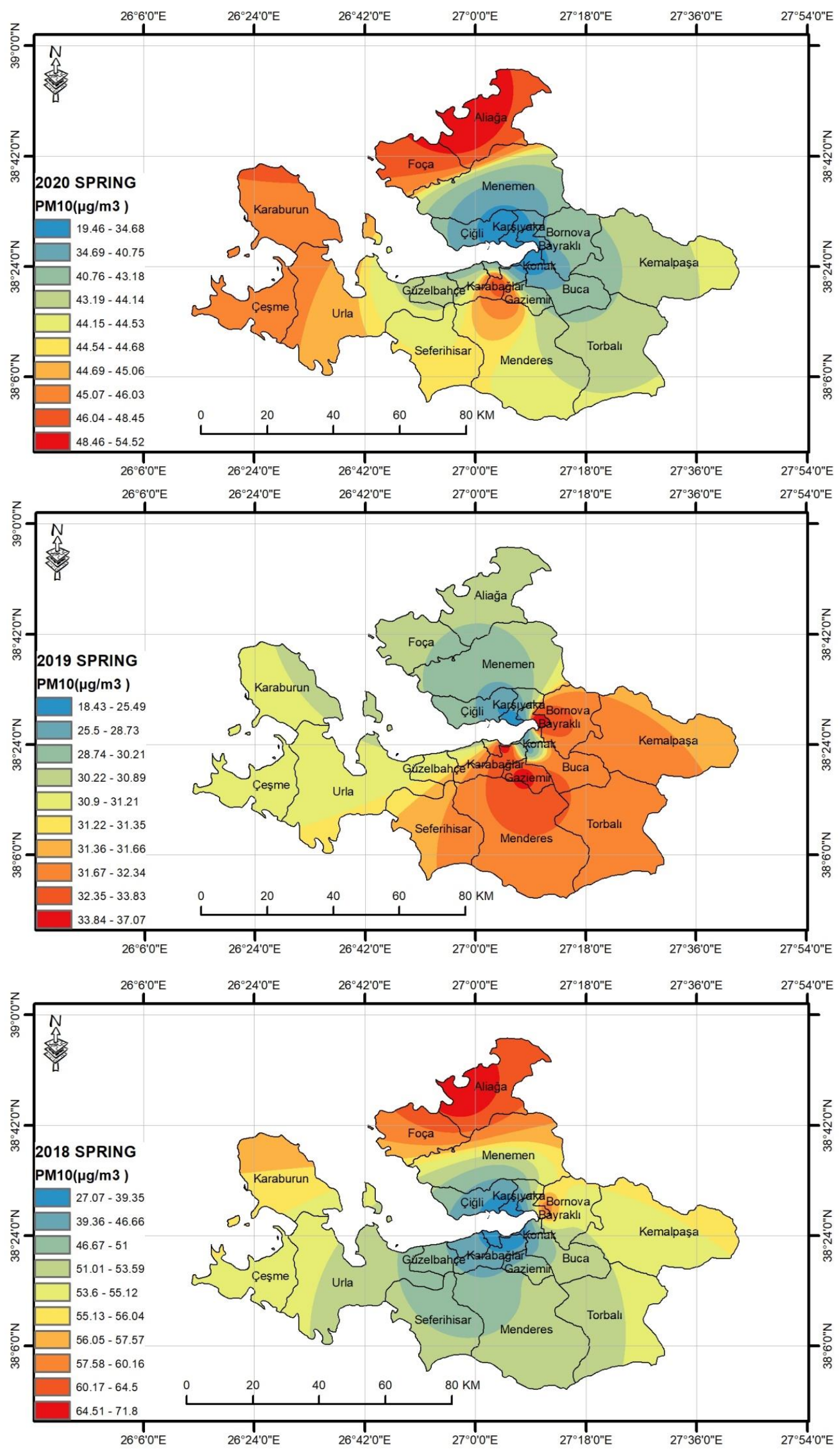

Figure 2. (a.a-c) Spring season average PM 10 distributions in the study area (2018-2019-2020) 

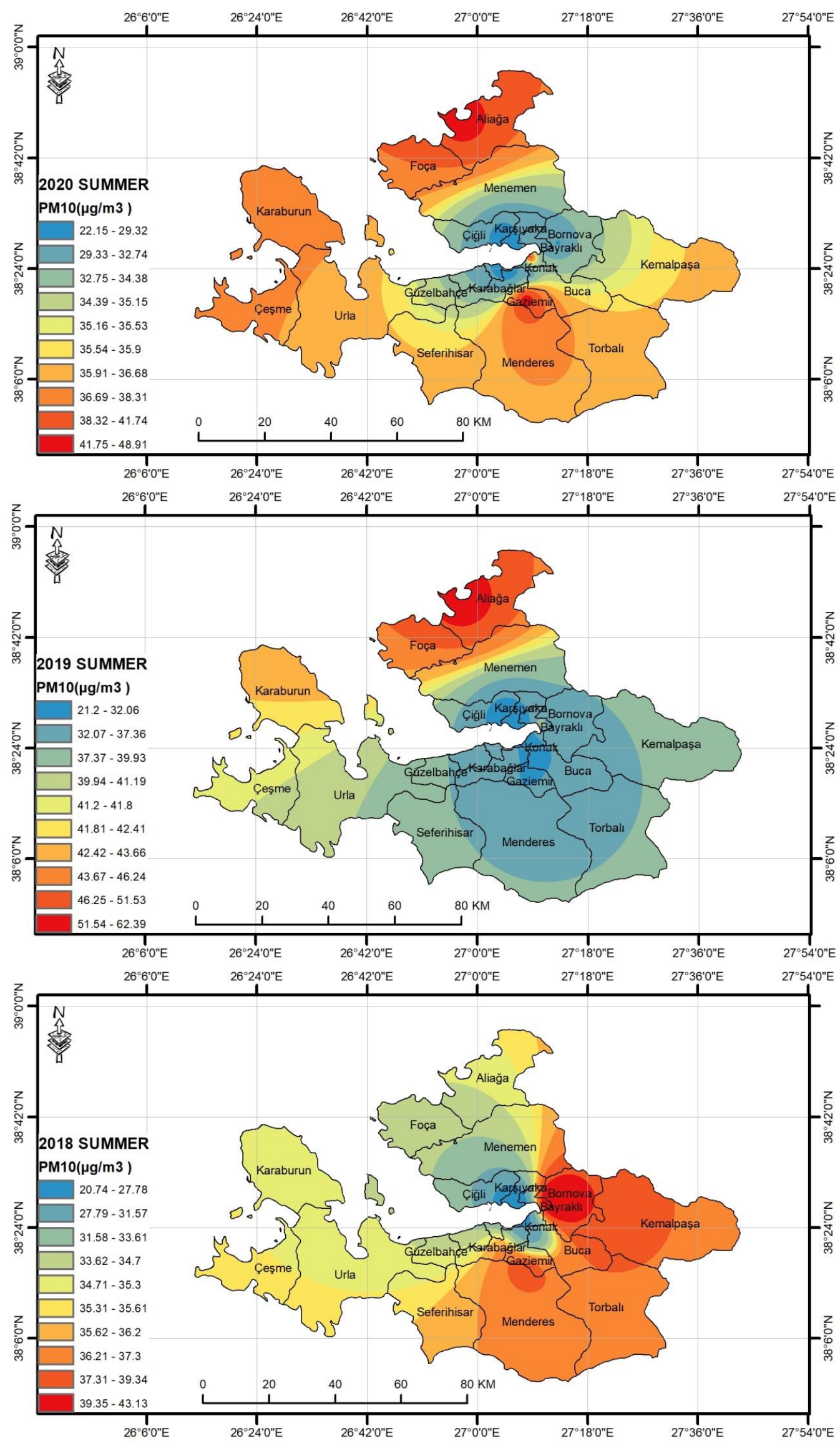

Figure 2. (b.a-c) Summer season average PM 10 distributions in the study area (2018-2019-2020) 

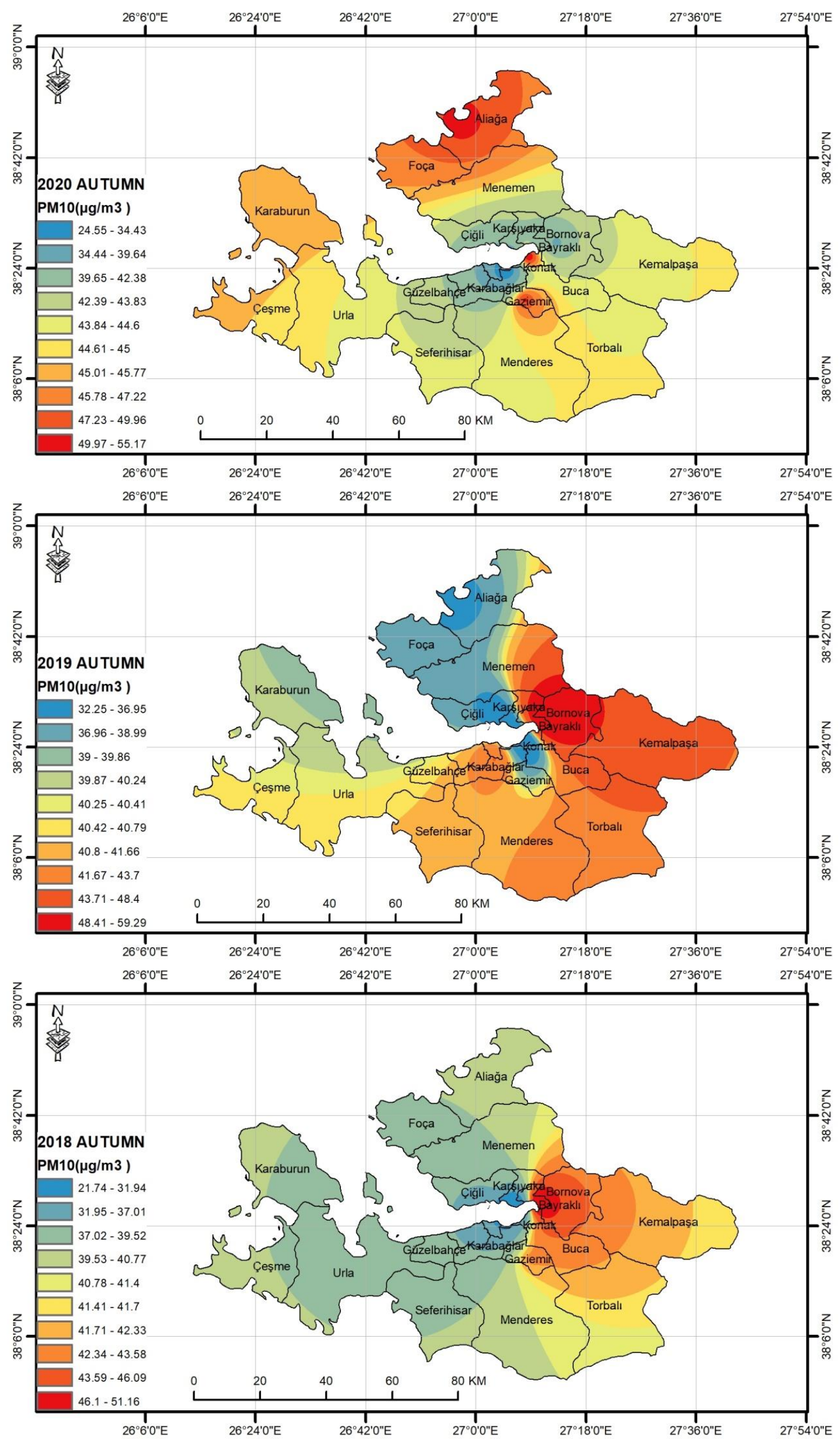

Figure 2. (c.a-c) Autumn season average PM 10 distributions in the study area (2018-2019-2020) 

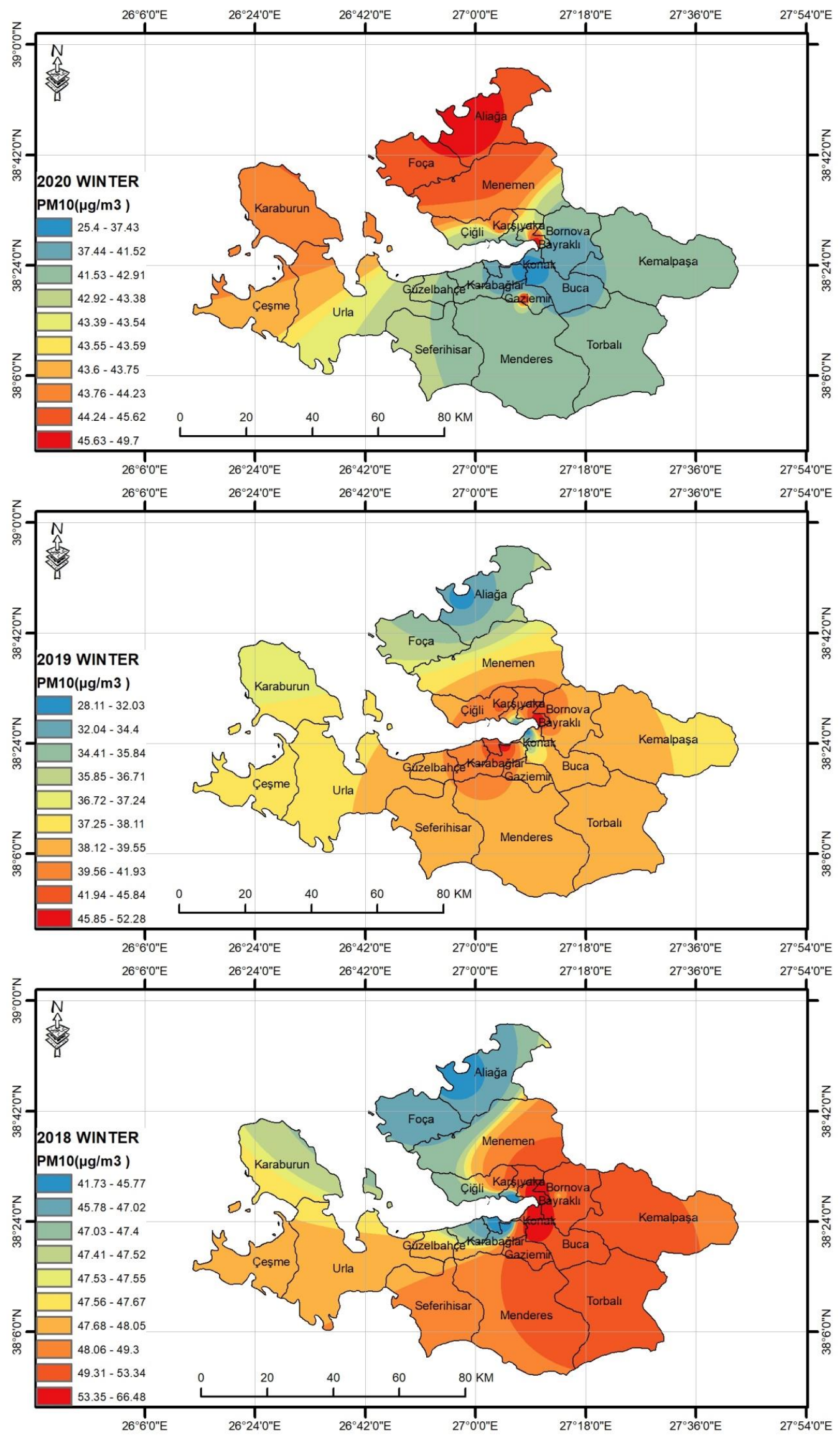

Figure 2. (d.a-c) Winter season average PM 10 distributions in the study area (2018-2019-2020) 


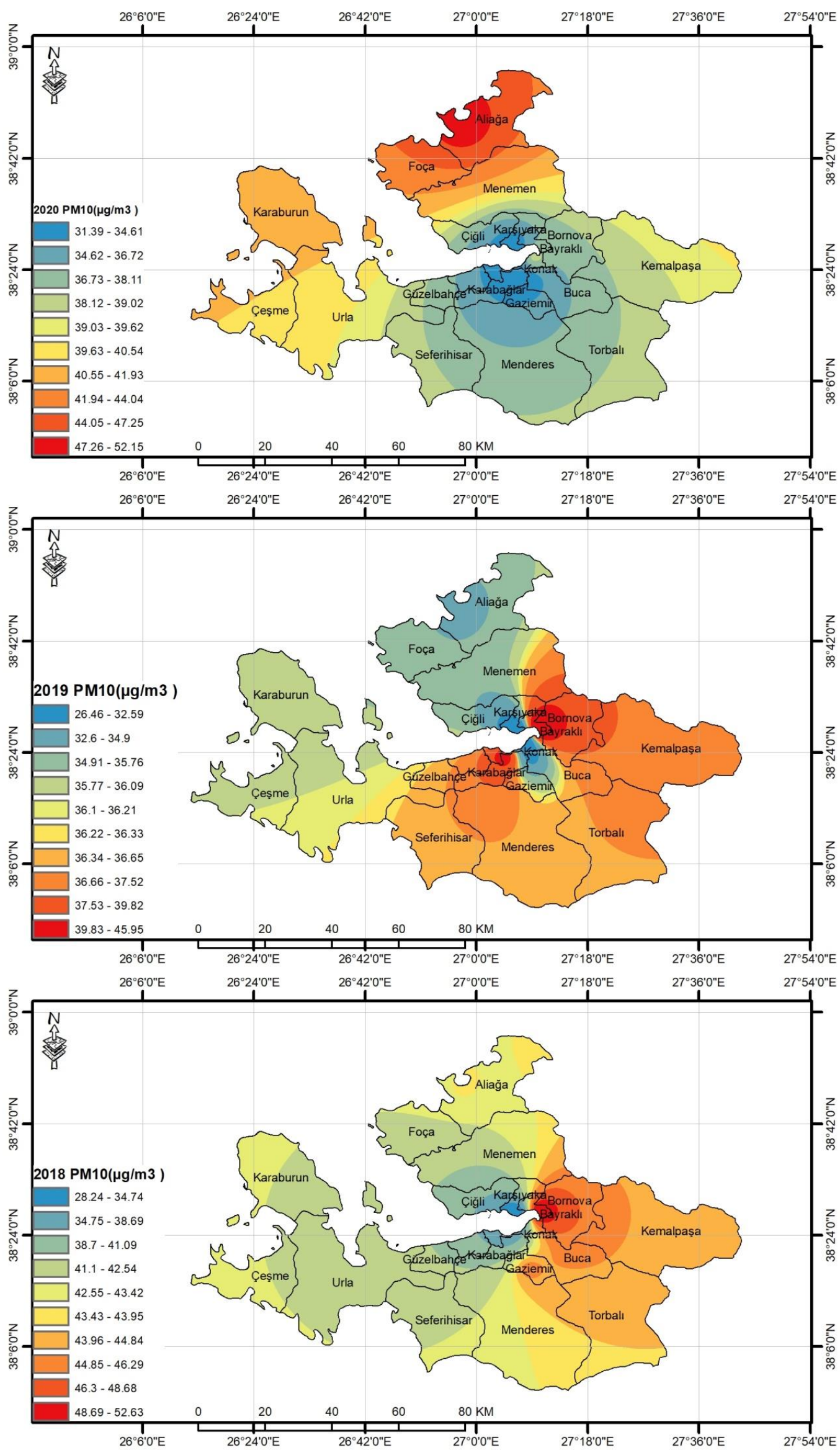

Figure 2. (e.a-c) PM10 distribution map according to the averages of 2018, 2019 and 2020 


\begin{tabular}{|c|c|c|c|c|c|}
\hline Stations & $\begin{array}{c}\text { Min. }\left(\mu \mathrm{g} / \mathrm{m}^{3}\right) \\
\text { Date } \\
\end{array}$ & $\begin{array}{c}\text { Max. }\left(\mu \mathrm{g} / \mathrm{m}^{3}\right) \\
\text { Date } \\
\end{array}$ & Mean $\left(\mu \mathrm{g} / \mathrm{m}^{3}\right)$ & $\begin{array}{l}\text { Number of daily limit } \\
\text { exceeded }\left(50 \mu \mathrm{g} / \mathrm{m}^{3}\right)\end{array}$ & $\begin{array}{c}\text { Number of days without } \\
\text { measurement }\end{array}$ \\
\hline Aliağa & $\begin{array}{c}10.05 \\
15.12 .2020\end{array}$ & $\begin{array}{c}157.22 \\
18.05 .2020\end{array}$ & 52.27 & 153 & 30 \\
\hline Alsancak & $\begin{array}{c}4.27 \\
07.01 .2020\end{array}$ & $\begin{array}{c}172.37 \\
03.12 .2020\end{array}$ & 37.83 & 75 & 20 \\
\hline Bayrakl1 & $\begin{array}{c}7.00 \\
27.05 .2020\end{array}$ & $\begin{array}{c}125.09 \\
15.01 .2020\end{array}$ & 37.43 & 80 & 17 \\
\hline Bornova & $\begin{array}{c}9.00 \\
29.02 .2020\end{array}$ & $\begin{array}{c}136.34 \\
20.05 .2020\end{array}$ & 37.18 & 67 & 28 \\
\hline Çiğli & $\begin{array}{c}4.57 \\
20.11 .2020\end{array}$ & $\begin{array}{c}131.42 \\
18.11 .2020\end{array}$ & 34.61 & 55 & 13 \\
\hline Gaziemir & $\begin{array}{c}13.17 \\
07.011 .2020\end{array}$ & $\begin{array}{c}120.19 \\
18.05 .2020\end{array}$ & 46.57 & 121 & 17 \\
\hline Güzelyalı & $\begin{array}{c}7.81 \\
11.01 .2020\end{array}$ & $\begin{array}{c}131.56 \\
15.01 .2020\end{array}$ & 31.43 & 48 & 9 \\
\hline Karşıyaka & $\begin{array}{c}5.43 \\
07.01 .2020\end{array}$ & $\begin{array}{c}111.51 \\
28.11 .2020\end{array}$ & 32.34 & 49 & 14 \\
\hline Şirinyer & $\begin{array}{c}4.00 \\
07.01 .2020\end{array}$ & $\begin{array}{c}106.95 \\
03.12 .2020\end{array}$ & 33.61 & 24 & 11 \\
\hline
\end{tabular}

Table 3. PM10 statistical values for 2020

\begin{tabular}{|c|c|c|c|c|c|}
\hline Stations & $\begin{array}{c}\text { Min. }\left(\mu \mathrm{g} / \mathrm{m}^{3}\right) \\
\text { Date }\end{array}$ & $\begin{array}{c}\text { Max. }\left(\mu \mathrm{g} / \mathrm{m}^{3}\right) \\
\text { Date }\end{array}$ & $\begin{array}{l}\text { Mean. } \\
\left(\mu \mathrm{g} / \mathrm{m}^{3}\right)\end{array}$ & $\begin{array}{l}\text { Number of daily limit } \\
\text { exceeded }\left(50 \mu \mathrm{g} / \mathrm{m}^{3}\right)\end{array}$ & $\begin{array}{c}\text { Number of days without } \\
\text { measurement }\end{array}$ \\
\hline Aliağa & $\begin{array}{c}17.46 \\
30.12 .2019\end{array}$ & $\begin{array}{c}61.27 \\
18.09 .2019\end{array}$ & 33.99 & 3 & 331 \\
\hline Alsancak & $\begin{array}{c}6.31 \\
31.12 .2019\end{array}$ & $\begin{array}{c}96.94 \\
18.11 .2019\end{array}$ & 31.06 & 36 & 18 \\
\hline Bayraklı & $\begin{array}{c}8.72 \\
31.12 .2019\end{array}$ & $\begin{array}{c}142.32 \\
26.01 .2019\end{array}$ & 44.62 & 95 & 15 \\
\hline Bornova & $\begin{array}{c}5.14 \\
14.02 .2019\end{array}$ & $\begin{array}{c}133.06 \\
25.01 .2019\end{array}$ & 41.26 & 93 & 20 \\
\hline Çiğli & $\begin{array}{c}10.67 \\
30.12 .2019\end{array}$ & $\begin{array}{c}111.71 \\
26.01 .2019\end{array}$ & 32.61 & 40 & 22 \\
\hline Gaziemir & $\begin{array}{c}10.15 \\
10.01 .2019\end{array}$ & $\begin{array}{c}95.58 \\
19.02 .2019\end{array}$ & 36.13 & 51 & 38 \\
\hline Güzelyalı & $\begin{array}{c}14.94 \\
10.15 .2019\end{array}$ & $\begin{array}{c}152.10 \\
26.01 .2019\end{array}$ & 40.65 & 70 & 7 \\
\hline Karşıyaka & $\begin{array}{c}5.05 \\
22.12 .2019\end{array}$ & $\begin{array}{c}134.50 \\
18.11 .2019\end{array}$ & 26.49 & 33 & 19 \\
\hline Şirinyer & $\begin{array}{c}5.34 \\
30.12 .2019\end{array}$ & $\begin{array}{c}97.47 \\
05.02 .2019\end{array}$ & 31.64 & 32 & 15 \\
\hline
\end{tabular}

Table 4. PM10 statistical values for 2019

\begin{tabular}{|c|c|c|c|c|c|c|}
\hline Stations & $\begin{array}{c}\text { Min. }\left(\mu \mathrm{g} / \mathrm{m}^{3}\right) \\
\text { Tarih }\end{array}$ & $\begin{array}{c}\text { Max. }\left(\mu \mathrm{g} / \mathrm{m}^{3}\right) \\
\text { Tarih }\end{array}$ & $\begin{array}{l}\text { Mean. } \\
\left(\mu \mathrm{g} / \mathrm{m}^{3}\right)\end{array}$ & $\begin{array}{l}\text { Number of daily limit } \\
\text { exceeded }\left(60 \mu \mathrm{g} / \mathrm{m}^{3}\right)\end{array}$ & $\begin{array}{l}\text { Number of daily limit } \\
\text { exceeded }\left(50 \mu \mathrm{g} / \mathrm{m}^{3}\right)\end{array}$ & $\begin{array}{c}\text { Number of days without } \\
\text { measurement }\end{array}$ \\
\hline Aliağa & $\begin{array}{c}19.04 \\
25.01 .2018\end{array}$ & $\begin{array}{c}92.21 \\
30.01 .2018\end{array}$ & 41.61 & 3 & 4 & 349 \\
\hline Alsancak & - & - & - & - & - & - \\
\hline Bayraklı & $\begin{array}{c}7.38 \\
30.11 .2018\end{array}$ & $\begin{array}{c}192.33 \\
30.01 .2018\end{array}$ & 51.84 & 98 & 135 & 11 \\
\hline Bornova & $\begin{array}{c}6.55 \\
30.11 .2018\end{array}$ & $\begin{array}{c}231.20 \\
23.03 .2018\end{array}$ & 48.59 & 89 & 123 & 19 \\
\hline Çiğli & $\begin{array}{c}7.83 \\
06.12 .2018\end{array}$ & $\begin{array}{c}136.21 \\
27.03 .2018\end{array}$ & 37.30 & 41 & 65 & 43 \\
\hline Gaziemir & $\begin{array}{c}9.05 \\
16.12 .2018\end{array}$ & $\begin{array}{c}154.52 \\
05.03 .2018\end{array}$ & 45.20 & 64 & 103 & 19 \\
\hline Güzelyalı & $\begin{array}{c}6.29 \\
27.05 .2018\end{array}$ & $\begin{array}{c}138.29 \\
27.03 .2018\end{array}$ & 36.07 & 34 & 52 & 19 \\
\hline Karşıyaka & $\begin{array}{c}3.01 \\
06.12 .2018\end{array}$ & $\begin{array}{c}126.48 \\
27.03 .2018\end{array}$ & 28.72 & 25 & 36 & 33 \\
\hline Şirinyer & $\begin{array}{c}10.70 \\
29.06 .2018\end{array}$ & $\begin{array}{c}167.43 \\
20.02 .2018\end{array}$ & 42.06 & 55 & 81 & 24 \\
\hline
\end{tabular}

Table 5. PM10 statistical values for 2018 
The RAQAM and EU limit values for 2018 are 44 and 40 $\mu \mathrm{g} / \mathrm{m} 3$, respectively. The WHO limit value is $20 \mu \mathrm{g} / \mathrm{m} 3$. RAQAM and EU daily limit values are 60 and $50 \mu \mathrm{g} / \mathrm{m} 3$, respectively, and the maximum number of days allowed to be exceeded is 35 .

The minimum, maximum and average values of PM10 values for 2018 are shown in Table 5. Bayraklı, Bornova and Gaziemir stations exceeded the RAQAM annual limit value for 2018 . Although only Çiğli, Güzelyalı and Karşıkaya did not exceed the EU limit values, all stations exceeded the WHO limit values. Aliağa, Güzelyalı and Karșıyaka stations have exceeded the daily limit of RAQAM. Only Aliağa station did not exceed the EU daily limit exceeded. However, the station that does not have the most data is Aliağa, as in 2019.

\section{CONCLUSION}

In this study, an evaluation was made according to the data of the air quality monitoring station in Izmir. In addition to statistical evaluations, evaluations were made on maps showing spatial PM10 distribution. Thus, the potential impact area of pollution was also seen. In smart city applications, these maps can be used as layers to monitor pollution intensity spatially. Local administrators can also instantly monitor situations that may pose a threat to sensitive people such as children, the elderly and the sick, thanks to the maps they create using hourly data. Scenarios can be produced to take precautions in possible adverse situations. In addition, possible sources can be interpreted more clearly with the help of these maps. It is observed that Aliağa and Gaziemir stations frequently exceed the legal annual and daily limits. In addition, as stated in the report of the İzmir Provincial Directorate of Environment and Urbanization, in this study, it was determined that the district with the highest air pollution was Aliağa, which stands out with heavy industry investments. It was observed that the annual average PM10 values were below the limit values, but the number of days that could not be measured was too high in this station for 2018-2019. Again, the contribution of industrial establishments located in the city center, especially in Bornova district, to air pollution can be seen from the results obtained. It can be said that the biggest contribution to air pollution caused by heating and traffic is the central districts.

\section{REFERENCES}

Abujayyab, S. K. M. and İ. R. Karaş. 2019. “Automated Prediction System For Vegetation Cover Based On Modis-Ndvi Satellite Data And Neural Networks." Int. Arch. Photogramm. Remote Sens. Spatial Inf. Sci. XLII-4/W19:9-15.

Abujayyab, S. K. M., M. S. S. Ahamad, A. S. Yahya, S. Z. Ahmad, and H. A. Aziz. 2017. "Automating an Integrated Spatial Data-Mining Model for Landfill Site Selection." in AIP Conference Proceedings. Vol. 1892.

Ayberk S. (2002). Hava Kirliliği ve Meteorolojik Olaylar, Kocaeli Üniversitesi Yayın No:83, Kocaeli.

Demirarslan, K. O. (2016). Kış kentlerinde 1sınma kaynaklı partikül maddenin hava kalitesi üzerine etkisi ve Doğu Anadolu Bölgesi Ağrı. Ardahan, Erzurum ve Kars illeri örneği, Uluslararası Kış Kentleri Sempozyumu, 10-12.
Demirarslan, K. O., \& Kaya, A. (2017). Kömür madenciliği kaynaklı hava kirliliği: partikül madde ve metan emisyonları üzerine literatür araştırması. Bilimsel Madencilik Dergisi, 56(1), 23-31.

Demirarslan, K., \& Akıncı, H. (2016). Doğu Karadeniz Bölgesindeki partikül madde dağılımlarının coğrafi bilgi sistemleri yardımıyla belirlenmesi. Doğal Afetler ve Çevre Dergisi, 2(1), 30-45.

Dorevitch, S., Demirtas, H., Perksy V.W., Erdal, S., Conroy, L., Schoonover, T., Scheff A.P. 2006. "Demolition of High-Rise Public Housing Increases Particulate Matter Air Pollution in Communities of High-Risk Asthmatics.” Air \& Waste Manage. Assoc. 56:1022-1032.

Eggleston, P.A., Buckley, T.J., Breysse, P.N., Wills-Karp, M., Kleeberger, S.R., Jaakkola, J. 1999. "The Environment and Asthma in US Inner Cities." Environ. Health Perspect. 107, 439.

Ergenekon, P., \& Ulutaş, K. (2014). Heavy metal content of total suspended air particles in the heavily industrialized town of Gebze, Turkey. Bulletin of environmental contamination and toxicology, 92(1), 90-95.

EU. 2008. Directive 2008/50/EC of the European Parliament and of the Council of 21 May 2008 on ambient air quality and cleaner air for Europe.Official Journal of the European Communities 152:1-43

Heal, M.R., Kumar, P., Harrison, R.M. 2012. "Particles, air quality, policy and health.” Chem. Soc. Rev. 41, 6606-6630.
IG
2021
Izmir
Governorship
http://www.izmir.gov.tr/ilcelerimiz

IPDEU 2021 izmir provincial directorate of environment and urbanism, IZMIR CEVRE VE SEHIRCILİK IL MÜDÜRLÜĞÜ İZMIR İLİ 2020 YILI ÇEVRE DURUM RAPORU, 2021

Janssen, N.A.H., Fischer, P., Marra, M., Ameling, C., Cassee, F.R. 2013. "Short-term effects of PM2.5, PM10 and PM2.5e10 on daily mortality in the Netherlands." Sci.Total Environ. 463$464,20-26$

Kan, H., London, S.J., Chen, G., Zhang, Y., Song, G., Zhao, N., Jiang, L., Chen, B. 2007. "Differentiating the effects of fine and coarse particles on daily mortality in Shanghai, China." Environ. Int. 33, 376-384.

Laxen, D. (1993). An introduction to local air quality management. A supplement to Clean Air, 23, 12.

MEU 2020. Cevre ve Şehirçilik Bakanlığ $\mid$ Ulusal Hava Kalite İzleme Ağı. https://sim.csb.gov.tr/Services/AirQuality

Namdeo, A., Bell, M.C. 2005. "Characteristics and Health İmplications of Fine and Coarse Particulates at Roadside, Urban Background and Rural Sites in UK.” Environ. Int. 31, 565-573.

RAQAM 2008. Regulation of Air Quality Assessment and Management. Ministry of Environment and Urbanisation, 26898, 06. 
Sivertsen, B., \& Bartonova, A. (2012). Air quality management planning (AQMP). Chemical Industry and Chemical Engineering Quarterly, 18(4-2), 667-674.

Spencer-Hwang, R., Knutsen, S.F., Soret, S., Ghamsary, M., Beeson, W.L., Oda, K., Shavlik, D., Jaipaul, N. 2011. Ambient air pollutants and risk of fatal coronary heart disease among kidney transplant recipients. Am. J. Kidney Dis. 58, 608-616.

Taşdemir, Y. (1999). Havadaki Partikül Maddelerin Su Kütleleri Üzerine Çökelmesinin Miktar ve Etkileri. 3. Ulusal Çevre Mühendisliği Kongresi.

Taşdemir, Y., \& Çağlar, Ö. (2002). Uludağ Üniversitesi Kampüsü'nde ölçülen partikül madde kuru çökelme akıları. Ekoloji Çevre Dergisi, 11(42), 8-11.

TUIK, 2021).https://data.tuik.gov.tr/Bulten/Index?p=37210

Turner, M.C., Krewski, D., Pope, C.A., Chen, Y., Gapstur, S.M., Thun, M.J. 2011. "Longterm Ambient Fine Particulate Matter Air Pollution and Lung Cancer in a Large Cohort of Never-Smokers.” Am. J. Respir. Crit. Care Med. 184, 13741381.

USEPA. Supplemental Guidance for developing soil screening levels for superfund sites. Office of Solid Waste and Emergency Response. OSWER 9355.4-24 Washington DC; 2002.

Uttara S, Bhuvandas N, Aggarwal V. 2012. Impacts of urbanization on environment. International Journal of Research in Engineering and Applied Sciences, 2(2):1637-1645.

Vineis P, Hoek G, Krzyzanowski M, Vigna-Taglianti F, Veglia F, Airoldi L, Autrup H, Dunning A, Garte S, Hainaut P, et al. Air pollution and risk of lung cancer in a prospective study in Europe. Int J Cancer 2006; 119:169-174

Weng, C.H., Hu, C.C., Yen, T.H., Huang, W.H., 2015. "Association between Environmental Particulate Matter and Arterial Stiffness in Patients Undergoing Hemodialysis." BMC Cardiovasc. Disord. 15, 115.

WHO 2005, WHO Air quality guidelines for particulate matter, ozone, nitrogen dioxide and sulfur dioxide. http://apps.who.int/iris/bitstream/handle/10665/69477/WHO_S DE_PHE_OEH_06.02_eng.pdf;jsessionid=73ACFD046B01336 03E451C69A53A1367? sequence $=1$ 